研 究

\title{
電解加工におけるチタン合金表面の不働態被膜の特性と 加工への影響
}

\section{Characteristics of Passivation Film on Titanium Alloy Surface in Electrochemical Machining and its Effect on Machining}

\author{
Saori HIZUME, Wataru NATSU
}

\begin{abstract}
In scanning electrochemical machining, in which the shape of the product is formed by scanning a tool with a simple shape, every machining point comes in touch with the current density in the order of low-current-density region, high-current-density region, and low-current-density region. In the machining of titanium alloys, which are prone to passivation, a strong passivation film is formed before the tool moves over the machining point. Therefore, the material cannot be eluted even when it comes in touch with the high-current-density region because of the thick film. In this study, to realize the practical use of scanning electrochemical machining, the thickness and residual stress of the passivation film generated on the surface of titanium alloy were measured. In addition, the effect of the passivation film on machining was investigated and discussed.
\end{abstract}

Key words : scanning electrochemical machining, passivation film, titanium alloys, current density, residual stress

\section{1. 緒言}

科学技術の発展にともない, 高機能材料の研究 が進み, 工業用材料の特性は高度化・高精度化し, 新たな加工法が求められる ${ }^{1)}$. 一方, 電解加工は化 学溶出作用を利用した除去加工法であるため, 金 属材料の硬さに影響されない, 加工速度が速い, 工 具消耗がないといった利点を持つ2). そこで, 電解 加工は難削材の加工への利用が再び期待されるよ うになった．現在生産現場で広く利用されるのは， 加工形状に合わせて設計・製作した高価な専用工 具を必要とする形彫り電解加工法である.

* 日本ルメンタム株式会社 デバイス開発センタ (神奈 川県相模原市中央区小山4-1-55)

** 東京農工大学 工学府 (東京都小金井市中町 2-24-16)
これに対し，個別部品に特化した特殊工具は不 要で, 低コストで柔軟な形状加工が実現できる走 查電解加工法も近年研究されている. これは, フラ イス加工のように単純な工具の走査によって形状 創成を行う方法であり, 多品種少量生産に電解加 工の適用範囲を拡大できる。

走査電解加工の例として, 小さなノズルから噴 出する電解液ジェットに電流を供給し，ノズルを 走查して複雑形状の加工を行う電解液ジェット加 工が挙げられる ${ }^{3,4}$. しかし，この方法には腐食性 のある電解液が飛散するという問題がある。一方, Yamamura ${ }^{5}$ は, 液の供給と回収を行う 2 つのポン プを使用して電解液を制限する同心円筒工具を提 案した。 また, Endoら 6は, 吸引ポンプ1つのみ 
で，電解液領域の制限と極間距離検出が同時に実 現する電解液吸引工具を提案した。これらの工具 を利用すれば，電解液が飛散せず走查電解加工が 実現できる.

吸引工具による走査電解加工では, Fig.1 に示寸 ように工具直下の電流密度は高いが，電極から離 れるほど電流密度は小さくなる。この状態で工具 を工作物面に走査すると, 加工点は低電流密度域, 高電流密度域, 低電流密度域の順に触れる. 不働態 になりにくいインコネルなどの材料加工には，大 きな問題が発生しないが, 不働態になりやすいチ タン合金などの加工では, 低電流密度域に触れる 時間が長いと, 加工より先に強固な不働態被膜が 生じるため高電流密度域を通過しても材料の溶出 ができなくなることが明らかとなっている ${ }^{7,8)}$. 不 働態とは，材料表面に酸化被膜ができる状態であ り, 本研究では, 酸化被膜を不働態被膜と呼ぶ.

チタンの不働態被膜の生成に関する研究が報告 されている. 例えば, Baehreら 9は, 電解液は酸化 被膜形成に重要な役割を果たすため, 異なる電解 液でのチタン合金の電気化学的溶解挙動を報告し, Wang $5^{10)}$ は, $\mathrm{NaNO}_{3}$ 電解液を使用した電解加工 でのチタン合金の陽極溶解特性を調査し, それら の溶解挙動を特徵付ける定量的溶解モデルを提案 している. 一方, 走查電解加工に関しては, 電解液 ジェットの走查速度を高速にすると, 低電流密度 領域の影響が小さくなり, 表面粗さが良好になる ことが報告されている ${ }^{11)}$.また, 筆者ら ${ }^{81}$ は電解液 領域を小さくするか吸引工具の走査速度を速くす

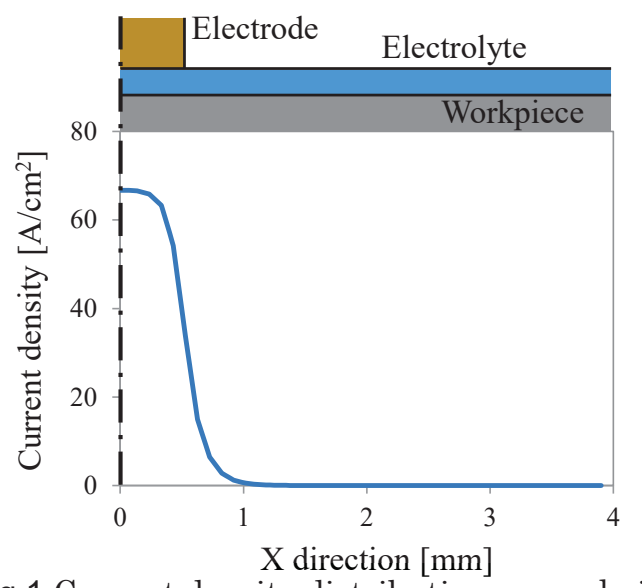

Fig.1 Current density distribution on workpiece surface
ることにより, 低電流域に触れる時間を短くして 不働態被膜の影響を低減し, チタン合金の走査加 工を実現できると報告している．また， Liu ら 12) は, 電解質である $\mathrm{NaCl}$ をエチレングリコール溶媒 に溶かし, 電解液ジェット加工に用いることで, 酸 化被膜の発生を抑制している.上記の研究は, 不働 態被膜の発生や抑制に関するもので, 不働態被膜 の厚さや残留応力などの特性, また, 被膜上の電解 加工特性は未だに明らかになっていない.

そこで, 本研究では, 走查電解加工の実用化に向 けて，不㗢態になりやすい材料の代表格であるチ タン合金の表面に発生する不働態被膜の厚さや残 留応力を調査する. なお, 不働態被膜を発生させた チタン合金に対して, 電解加工を行い, 不働態被膜 が加工に及ぼす影響を明らかにする。

\section{2. 不働態化しやすい材料の走査電解加工の問題点}

\section{1 加エシステム}

本研究に使用する工具および電解加工システム をFig. 2 に示す.工具は $1 \times 1 \mathrm{~mm}$ の真鍮製棒状電極 の周囲をアクリル部品で覆われている，電極端か ら左右に $4 \mathrm{~mm}$ ずつ離れた位置に電解液の流入・流 出口が設けられている. 電解液が工具下から溢れ ると装置の腐食などにつながるため, それを防ぐ ために, 電解液の流入口は直径 $3 \mathrm{~mm}$ と, 流出口の $2 \mathrm{~mm}$ に比べ大きくなっている. 極間距離が広い状 態で吸引ポンプを用いて吸引すると空気が吸引さ れるが, 極間距離が狭くなると, 極間に流入する空 気の速度が速くなり, ベルヌーイの定理より, 負圧 が生じる。これにより, 空気だけでなくタンクから

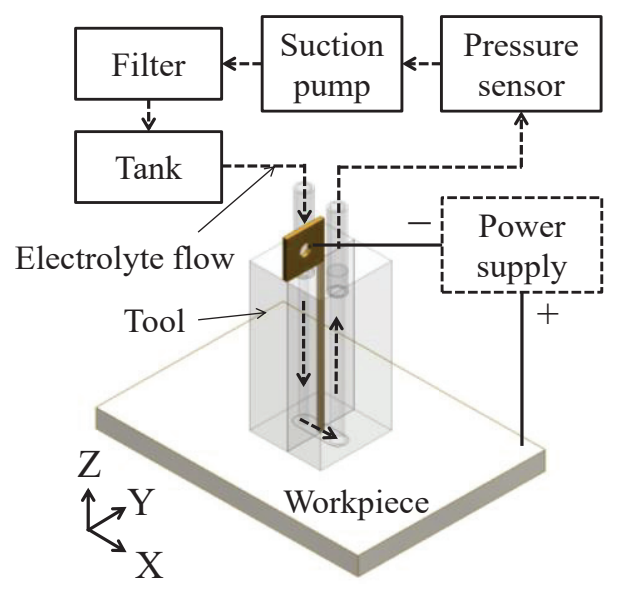

Fig.2 Machining system 
電解液が流入する。このようにして吸引ポンプ一 つで電解液は循環する.この時, 極間距離によって 吸引圧力が異なる ${ }^{6,13)}$ ため, 圧力センサーで吸引圧 力を測定すれば, 極間距離を検出できる. 加工開始 時の極間距離も吸引圧力によって設定する. 工具 を動かさずに電圧を印加すると，工具の底面積に およそ等しい範囲が加工される. 対して, 工具を工 作物の加工面に沿って走査すると, 工具の底面積 以上の領域が加工できる. 本論文では, 工具の走查 は全て Fig.2 に示す X 軸方向のみ行い, $\mathrm{Y}$ 軸およ びZ 軸への走查は行っていない.

電解液は, 流入口から流出口に向かって工具底 面に介在する. 工具直下の電解液の介在領域を調 べるため, チタン合金の代わりにガラスプレート を設置し, 工具他の装置を取り付け, 電解液を流し た状態で底面を観察した. その結果, 実際に観察さ れた電解液領域を Fig.3に示す.また, 速度 $1.5 \mathrm{~mm} / \mathrm{s}$ まで工具を往復走查した場合の観察実験により電 解液の濡れ広がり面積の大きさは変化することな く, 一定であることを確認した. 電解液が存在する 領域に電流が流れるため, 電圧印加時には, 電解液 を介して, 眓に示した領域で電流が流れることと なる。

\section{2 吸引工具を用いた走査電解加工と問題点}

Table 1 の条件で行ったチタン合金の電解加工 結果を Fig.4 に示す. 工作物の加工面は, $3 \mu \mathrm{m}$ の ダイヤモンドスラリによるラッピング加工後, 24 時間以上室温の空気中に放置して使用した. Fig.4

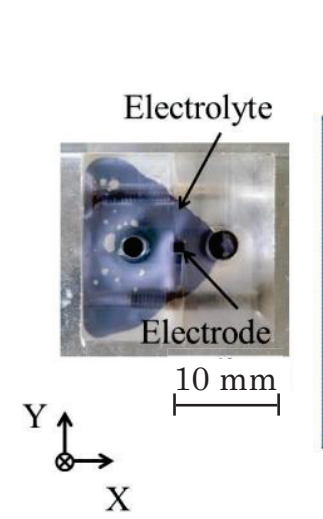

(a) Directly observed result

Fig.3 Electrolyte area under tool electrode
Table 1 Experimental conditions

\begin{tabular}{c|c}
\hline Electrode material & Brass \\
\hline Workpiece material & Ti-6Al-4V \\
\hline Initial gap & $0.07[\mathrm{~mm}]$ \\
\hline Applied voltage & $20[\mathrm{~V}]$ \\
\hline Pulse width & $5[\mathrm{~ms}]$ \\
\hline Pulse period & $50[\mathrm{~ms}]$ \\
\hline Electrolyte & $15 \mathrm{wt} \% \mathrm{NaCl}$ aq \\
\hline Flow rate & $0.56[\mathrm{~mL} / \mathrm{s}]$ \\
\hline
\end{tabular}

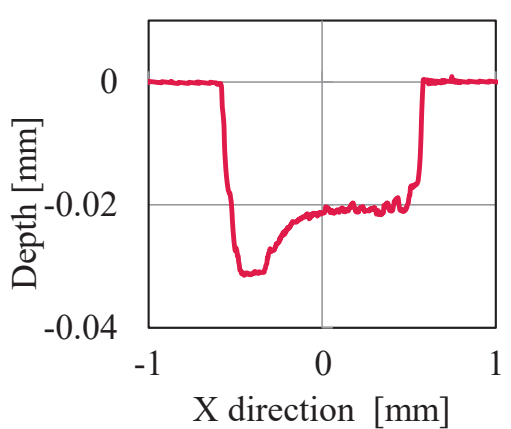

(a) Stationary ECM

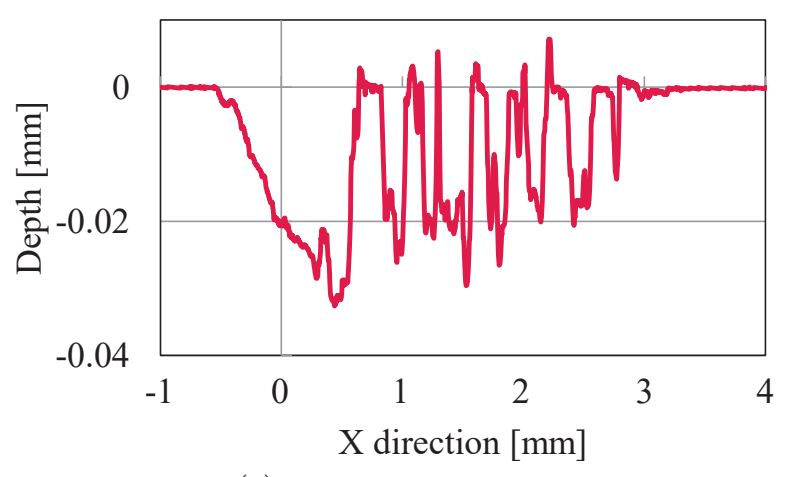

(b) Scanning ECM

Fig.4 Cross-sectional shape of machined mark

（a）は工具を動かさず，20 秒間加工した加工痕の 測定結果である. (b) は走查速度 $0.05 \mathrm{~mm} / \mathrm{s}$ で X 軸 正方向に $3 \mathrm{~mm}$ 走査した場合の結果である.これ は，走查線上における電極の滞在時間が（a）と等 しくなるようにしたものである，形状測定は輪郭 形状測定器 (Mitsutoyo, CV-3100S4) によって, 電 解液流れ方向である X 軸正方向に向かって行った。 なお，電極中心の初期位置は X 軸 $0 \mathrm{~mm}$ としてお り, 以降の図においても同様である. Fig.4 より, 走査しない場合には電極下全体が加工可能である 
にもかかわらず, 走查電解加工では, 加工される箇 所とされない箇所が生じ，まばらな加工となるこ とが分かる. なお，Fig.4（a）において左側，電解 液の流入口側で加工深さが大きいが，これは新鮮 な電解液が流入することによって加工が進行する ためである. 電解生成物の除去が行われるよう, 十 分な流速とパルス電圧を用いているため, 途中か らは加工量が一定となっていると考えられる. 走 查によって均一な加工痕が得られなければ, 単一 工具により目的形状を創成することができない. この原因が不働態被膜にあると考え, 次項の方法 でその原因を検証した。

\section{3 不均一加エが生じる理由と被膜の影響の調}

\section{查方法}

チタン合金は不働態になりやすい材料であるた め, 不働態被膜が生成されることで加工を妨げ, 被 膜の破壊によって不均一な溶出が生じること ${ }^{14) か ゙ ~}$ 考えられる. 走查電解加工でのみ不均一な溶出が 生じるのは, 電極周囲に広がる電解液により加工 が生じる前にも小さな電流が流れ不働態被膜が生 成されることが原因であると思われる，実際に吸 引工具によるチタン合金の電解加工後の表面を酸 素について, 電子線マイクロアナライザ（島津製 作所社製 EPMA-1720H）により元素マッピングを 行った. 走査せずに, Table.1の条件で 20 秒間加工 した加工痕を中心として測定した結果を Fig.5 に 示す. 電極と対向する部分では酸素量が多く, 周囲 に向かって減少するものの, 未加工面よりも多く の酸素が検出された. 電極下だけでなく, 左側にも 酸素が多い部分が分布しているが，電解液流れ方

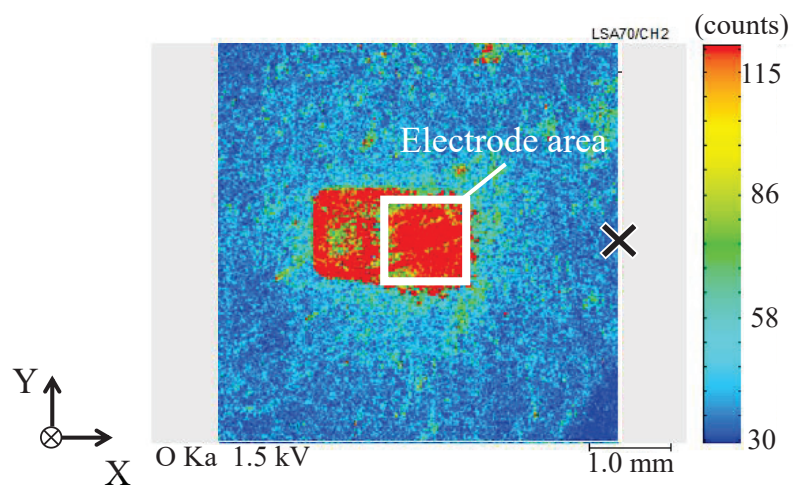

Fig.5 Elemental mapping results (O) on the surface of titanium alloy after ECM and analysis
向に沿っており, 電流密度が比較的高くなる左側 で酸素の発生も多くなることが考えられるが，原 因は不明である.また, 実際に不㗢態被膜の発生状 況やその被膜が走查電解加工に与える影響がまだ 明らかになっていない. そこで, 被膜が生成すると 考えられる低電流密度領域について, 不働態被膜 の発生状況と厚さ, 残留応力を調查する. なお, 本 報における低電流密度領域は, 電極下以外の周囲 に広がる電解液によって電流が流れる領域とする。

電極直下の加工が生じる場所の周囲で不働態被 膜が生成されるはずであるため, 測定箇所は Fig.5 に記号 $\times$ で示した, 加工痕から X 軸正方向に 2 $3 \mathrm{~mm}$ 程離れた辺りとする. また, 被膜は電圧印加 時間の影響を受けるため, 電圧印加時間は, 0 秒 (電 圧印加なし)，5秒，30 秒の 3 条件とした. その他 は Table 1 と同様である. なお, デューティ比 $10 \%$ であるので，パルスオン時間のみの合計は，0 秒， 0.5 秒, 3 秒となる.

\section{3. 低電流密度領域に生成する不働態被膜の特性 \\ 3.1 不働態被膜厚さ}

不働態被膜の生成時間が長いほど, 被膜は厚く なると考えられる. そこで, 電圧印加時間によって 実際に被膜が厚く成長しているのかを調査した。 工作物として使用した Ti-6Al-4V の場合には, およ そ $90 \%$ \%゙チタンであるため, 不働態被膜は主に $\mathrm{TiO}_{2}$ からなることが考えられ, 深さが異なる場所 の酸素量を比較することで被膜厚さの目安とする。 分析元素は, $\mathrm{Ti}, \mathrm{O}, \mathrm{Al}, \mathrm{V}, \mathrm{C}, \mathrm{Cl}$ とし, X 線光電 子分光分析装置 (日本電子, JPS-9010TR) によるデ プスプロファイルを行った. エッチングレートは 分析結果の変化が安定するまで 1 秒ごと, その後 変化がなくなるまで 5 秒ごととした. エッチング はXPS のエッチング機構を用い, Arイオンビーム を加速電圧 $500 \mathrm{~V}$, エミッション電流 $8.6 \mathrm{~mA}$ の条 件で行った。エッチングレートは, $\mathrm{SiO}_{2}$ 換算で $250 \AA / \mathrm{min}$ であり, Ti 単体では $150 \sim 380 \AA / \mathrm{min}$ と なる.しかし, チタン合金のエッチング量は不明で あり, $\mathrm{Ti}$ と $\mathrm{TiO}_{2}$ でも異なるため, 正確なエッチン グレートは不明である。 
分析結果を Fig.6 に示寸. $\mathrm{Cl}$ についてはいずれ においても検出されなかったため, 載せていない. Ti-6Al-4V の組成を考慮すると，合金内部に実際に 20 \%程度の C を含有していることは考えにくいが， 半定量分析のアルゴリズムにより C と同定された X線エネルギーは表面と内部で異なっているため, 他の元素とのスペクトルの干渉が生じこのような 結果となったと考えられる. しかし, 酸素量の変化 の傾向をつかむことを目的とした本研究において は問題なく, この結果を用いる. また，Fig.7に 0 〜30 秒までの酸素の結果の夕, 全条件まとめて示 す. 全ての結果において, 最表面には炭素が多い結 果となった. エタノールで表面洗浄を行ったため,

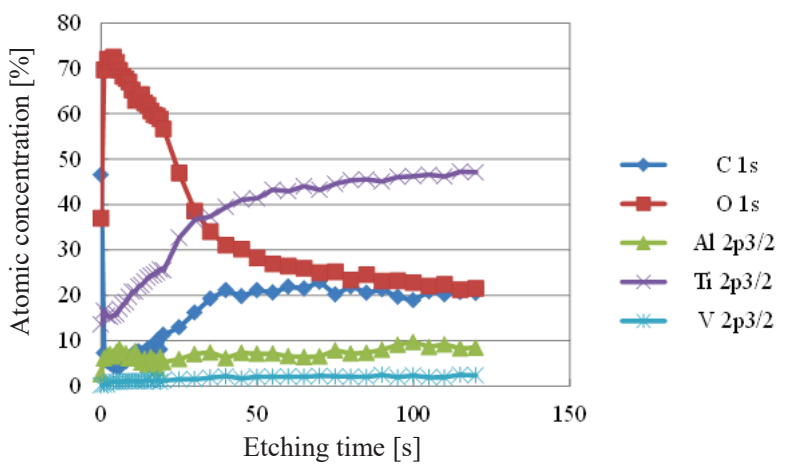

(a) Before applying voltage

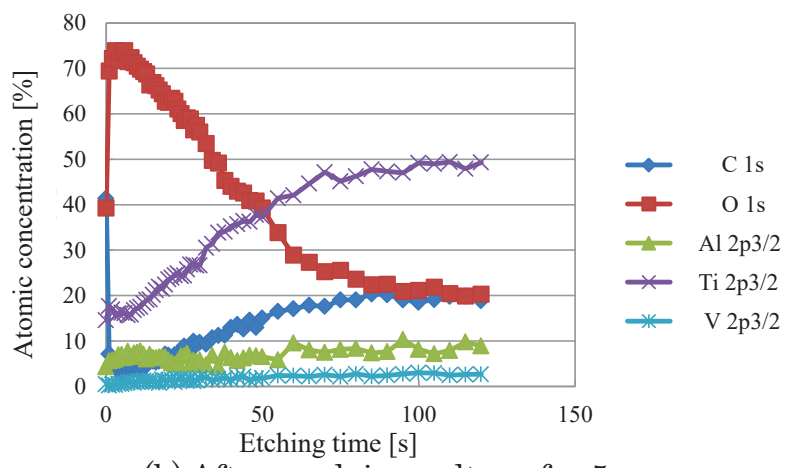

(b) After applying voltage for $5 \mathrm{~s}$

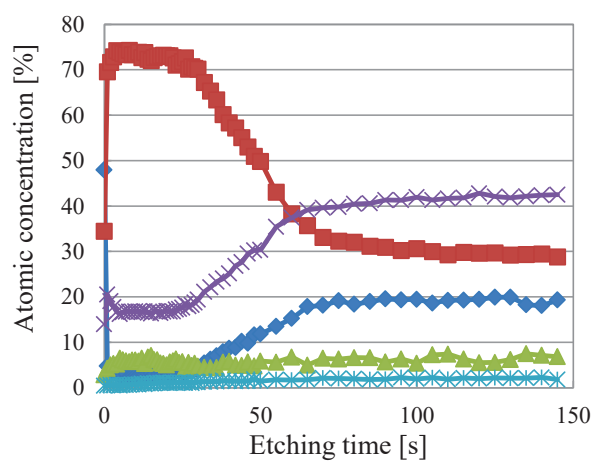

(c) After applying voltage for $30 \mathrm{~s}$

Fig.6 Depth profile of passivation film
有機残りが生じた，もしくは, 電解加工の前加工と して，ダイヤモンド砥粒を用いたラッピング加工 を行っているため, 洗浄後も砥粒が残り，このよう な結果となったことが考えられる．Fig.6，7より， どの条件でも, 表面に近いほど, 酸素が多く, 深く なるほど酸素は少なくなることが分かる. Fig.6 (a) は電圧印加前の面であるが，空気中の酸素と反応 し形成された，自然酸化被膜が存在する. Fig.7 よ り, 連続して酸素割合が減少する直前のエッチン グ時間は，(a) 未加工面ではエッチング時間 5 秒,

(b) 電圧印加時間 5 秒では 8 秒，(c) 電圧印加時 間 30 秒では 26 秒であった。この部分が被膜厚さ に対応していると思われる. そのため, 電圧印加時 間 30 秒の場合，チタン合金のエッチングレートは 不明であるが， $150 \AA / m i n$ と仮定した場合は，厚さ

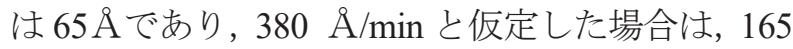
凡である. 本研究の実験条件においては, 不働態被 膜の厚さは数十〜百数十 $\AA$ オーダーと推定できる また Fig.6より，その後は（a）で 40 秒，(b) で 60 秒，(c) で 70 秒程度まで酸素が減少し，それに対 応するようにチタンは増加しているため，この間 は徐々に $\mathrm{TiO}_{2}$ が減少し金属のチタンが増加してい る. この分析結果から, 電解加工時の低電流密度領 域では不働態被膜が形成されており，被膜生成時 間が長いほど被膜が厚くなることが明らかとなっ た.

\section{2 被膜の残留応力}

被膜の機械特性を知るために, 残留応力に着目 して調查した. X 線残留応力測定装置 (パルステッ ク工業， $\mu-\mathrm{X} 360 \mathrm{~s}$ ）を用い，試料は前章と同様に電 圧印加なし, 電圧印加時間 5 秒および 30 秒とした. 湘定範囲は $\varphi 2.0 \mathrm{~mm}$, 深さ $10 \mu \mathrm{m}$ であり，その領

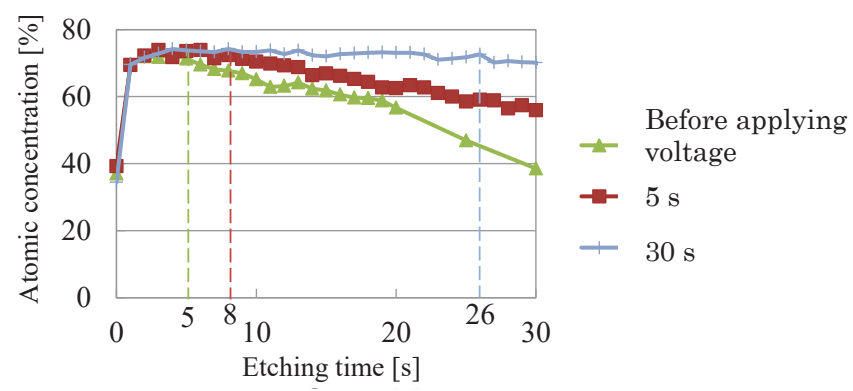

Fig.7 Time when the percentage of oxygen begins to decrease 
域の平均值が測定される.なお，3.1 節より被膜厚 さは, エッチングレートが $380 \AA / \mathrm{min}$ であるとする と, 最も厚くても $165 \AA$ 程度であり, 残留応力測定 深さよりも薄いため, 被膜と母材を合わせた残留 応力が測定される. 電解加工前の工作物を測定し たところ, 圧縮応力が測定され, 異なる試験片によ って-50〜-500 MPa と差が大きいことが分かった. これは, 購入素材の前加工の際に生じる残留応力 の影響であると考えられる. 圧延工程等, 前加工に おいて-500 MPa 程度の圧縮応力が与えられており ラッピングにより残留応力のある層が徐々に取り 除かれていくが，ラッピングの深さが異なるため, 大きな違いがあったのだと考えられる. そこで, 被 膜生成前に一度残留応力を測定し, 同程度の值が 得られた箇所でそれぞれ 5 秒，30 秒間電圧を印加 し, 被膜を生成し, 再度測定を行うことで, 被膜の 残留応力を比較する.

測定結果をFig.8 に示す. 未加工面との残留応力 の差は，被膜生成時間 5 秒の場合には $12 \mathrm{MPa}, 30$ 秒の場合には $28 \mathrm{MPa}$ である. 電解作用により被膜 が生成される時間が長くなるほじ，すなわち被膜 厚さが厚くなるほど残留応力の值は正方向に変化 した.このことより, 被膜は引つ張り方向に応力が 働いていることが分かる. 前述のように, これらの 残留応力測定は母材を含め, 被膜厚さ以上の範囲 の平均值であるので，実際には被膜部分にもつと 大きな引張応力がかかっていると考えられる. 被膜に生じる引張応力は, 酸素と結合することに よる体積膨張の影響 15)であると考えられる. 被膜 の破壊は微小な孔やクラックにより局所的に発生 することが知られ 16,17)，このことにより，被膜上で は引っ張り方向に力が働き, 被膜の局所的な破壊

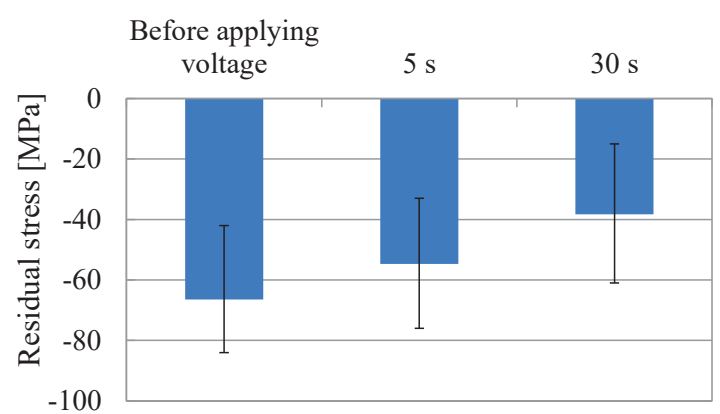

Fig.8 Measurement result of Residual
につながり，不均一な加工へと至ることが考えら れる.

\section{4. 被膜上の電解加工実験と考察 4. 1 実験方法と評価方法}

生成された被膜上に電極を移動し再度電圧を印 加することで, 走查電解加工における不働態被膜 の影響を実験的に検証した．実験の概略図を Fig.9 に示す. 2.1 節で示したように電解液は Fig.3 のよ うに広がっているため, 被膜を生成させる電圧印 加後に X 軸正方向に $2.5 \mathrm{~mm}$ 移動させ, 再度電圧を 印加した. これにより，Fig.9に示したように，電 解液領域は広がっており, 電流が流れるため周囲 では被膜が生成されるため, 二度目の加工は被膜 上で行われる. 被膜を生成させる電圧印加時間を 0 から 30 秒まで変化させ, 被膜上での加工時間は全 条件で 5 秒間とした. その他の実験条件は Table 1 之同様である. 被膜生成の電圧印加から電極移動 し被膜上加工までの時間は被膜生成時間 0 秒以外 の条件では 10 秒とした。 その間電解液は流したま まであり, 電解加工を行う工作物表面は空気中に 触れることはない. また, 加工後の工作物は, Fig.9 の黄線で囲った辺りを光学顕微鏡 (KEYENCE,
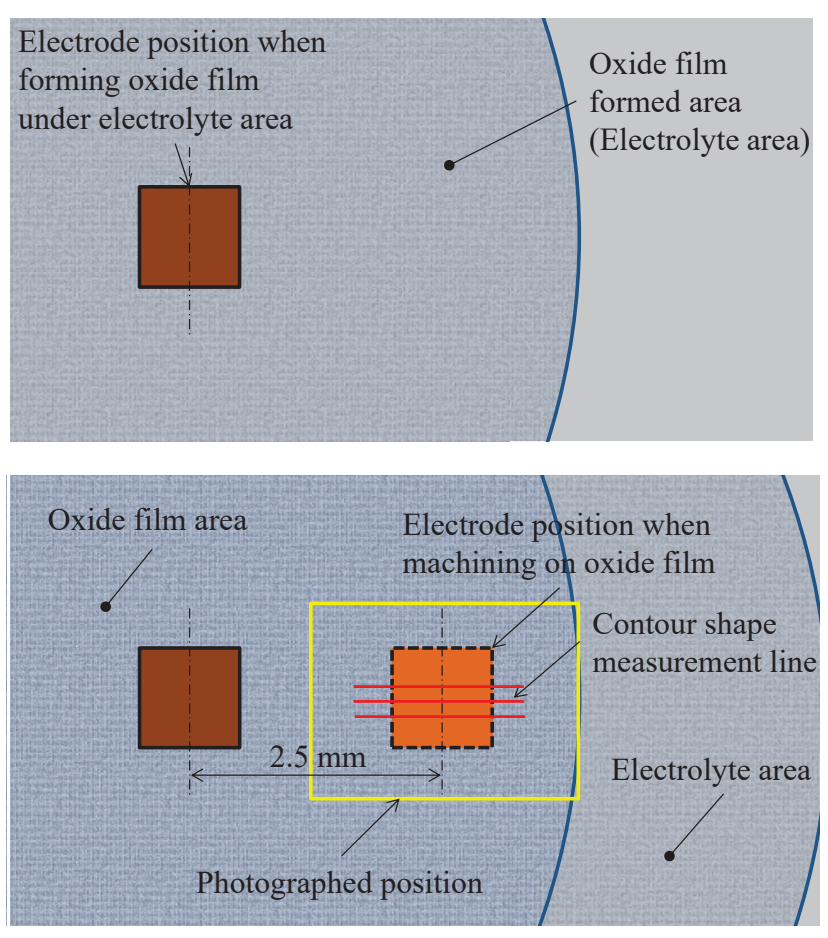

Fig.9 Schematic view of the applied voltage place and photograph area 
VW-9000）により撮影し，赤線のように X 軸方向 に $0.2 \mathrm{~mm}$ 間隔で 3 か所の輪郭形状測定を行うこと で評価する．測定ピッチは $0.001 \mathrm{~mm}$ である.

\section{2 電解加工結果}

加工痕の写真例および輪郭形状測定結果から算 出した加工量を Fig.10, Fig.11 に示す. Fig.10の白 い四角は工作物に対面する電極部分であり，黒く 見える箇所が除去加工の生じた部分である. Fig.11 の加工量は，前節の 3 か所の測定結果から求めた 加工断面積の平均である. Fig.10より，（c）1 秒よ りも被膜生成時間が長くなると，黒く除去加工が 生じた点が電極から離れた箇所でも見られるよう になり，電極下においても加工されない箇所が生 じることが分かる.また, 被膜生成時間が長くなる ほど被膜は厚くなるが，Fig.11 より，加工量は被膜 生成時間が 5 秒まで徐々に減少し，その後は増加 する結果となった． 0.1 秒， 5 秒， 30 秒での加工痕 の輪郭形状測定結果例を Fig.12 に示寸，それらを 比較すると， 0.1 秒では電極下の全体が加工されて いるのに対して， 5 秒，30 秒の場合には，加工がま ばらになっている。 0.1 秒と 30 秒では加工量は同 等であるが，30 秒の方が加工が生じる範囲が増加 し，局所的な加工量も増加していることが分かる. 3.2 節より, 被膜には引張忘力が働くことから, 被
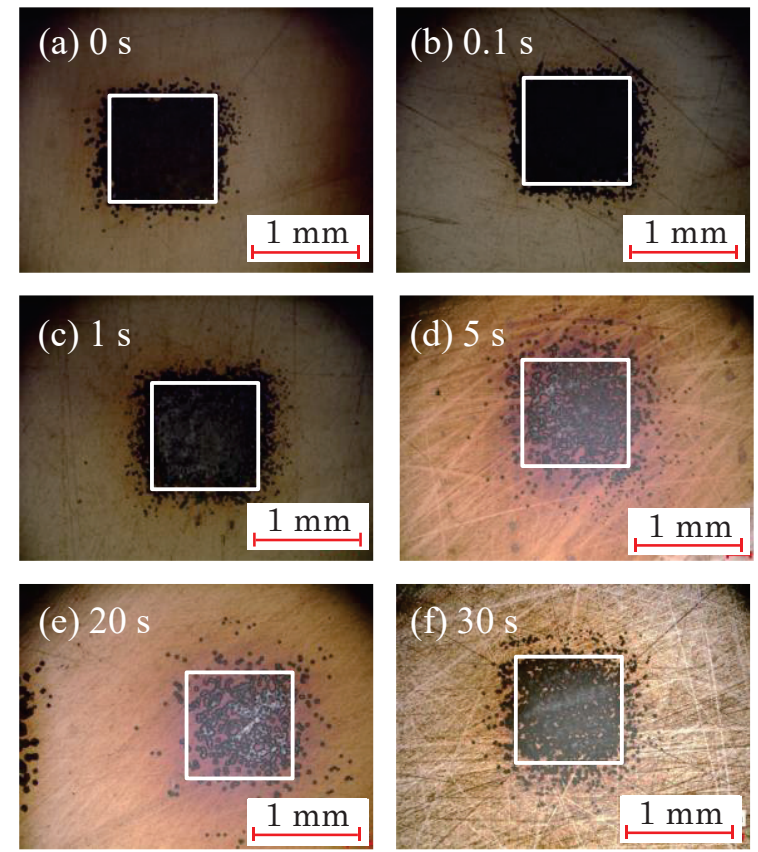

Fig.10 Machined marks on oxide film
膜が厚くなると大きな力で引っ張られ，局所的な クラックや孔が生じやすくなり，加工量が増加す るものと考えられる．また， 5 秒と 30 秒を比較す ると, 30 秒の方が加工深さが深くなるのと同時に, 除去加工が生じた点の数も，より多く見える. その ため, 被膜上での電解加工は, クラックの進展と被 膜全体一の加工の進展が同時に生じていると考え られる．ただし，25 秒で加工量が急増する理由に ついては不明であり，今後より詳細に調査する必 要がある.

\section{3 考察}

前節および前項の結果より，被膜が厚くなるこ とによる加工の妨げとそこに生じるクラックや孔 の発生による加工の促進作用はトレードオフの関 係にあると考えられる。 $20 \mathrm{~V}$ では 0.5 秒の低電流 密度にさらされることにより加工の妨げが最も大 きくなる，それ以上の低電流密度にさらされる時 間があると，被膜の成長に比べて破壊されやすく なる要素が大きくなり, 徐々に加工量は増加する. 被膜が薄い場合には, 強固な被膜であり, 電流密度

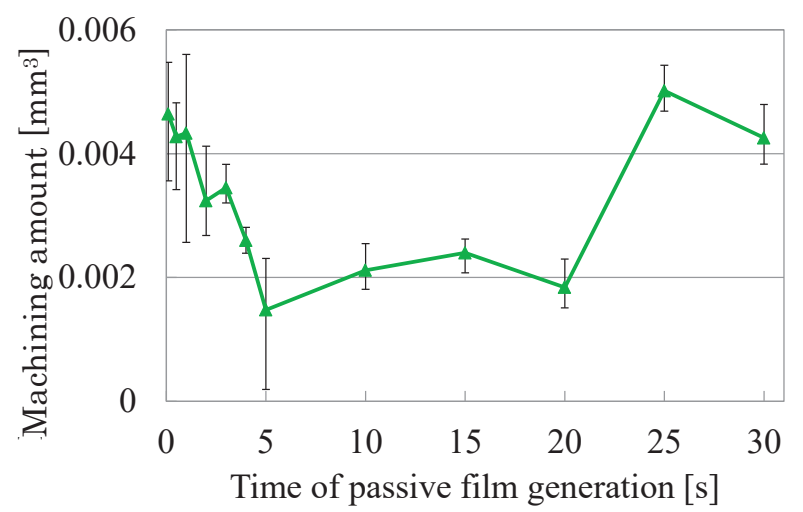

Fig.11 Relationship between the removed material and the time of generating film

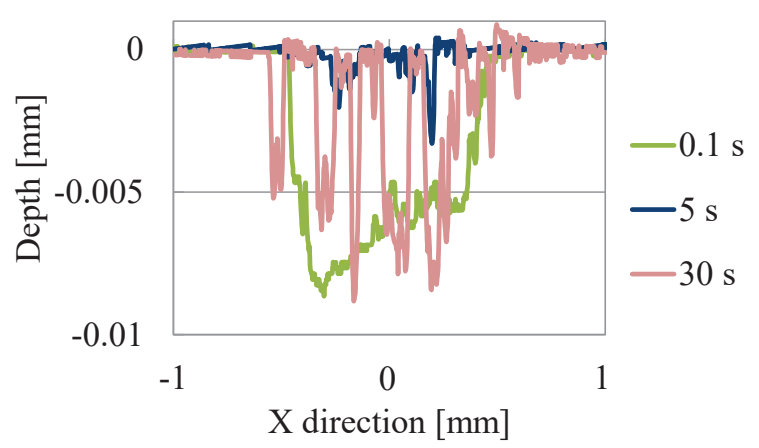

Fig.12 Contour shape measurement results 
が高い箇所が優先的に加工されることになる。一 方で，低電流密度時間が長く被膜が厚くなる場合 には，電極から離れた場所でも被膜の成長に伴い クラックや孔が発生することで，そこにも電流が 流れや寸くなり，加工が進行すると考えられる.

ところで，チタン合金の電解加工において工作 物表面に発生する不働態被膜の厚さと残留応力, そして不働態被膜が加工特性に及ぼす影響は電解 質, 溶媒, 加工条件によって大きく変化する. 本研 究は， 1 種類の電解液しか使用しておらず, 加工条 件も限られている. 今後は, 電解液の種類, 加工条 件とチタン合金の電解加工における不働態被膜の 特性, 電解加工特性の相関を実験的に, 理論的に解 明して行くと考えている.

\section{5. 結言}

不働態になりやすいチタン合金の電解加工にお いて, 低電流密度領域で生成される不働態被膜の 厚さや残留応力, また, 被膜が加工への影響を実験 的に調查し, 以下の知見を得た。

（1）低電流密度領域にある場所では，不働態被膜 が生成され，生成される時間が長いほど不働 態被膜は厚くなる

（2）本研究の実験条件では，不働態被膜の厚さは 数十〜百Aオーダーである

（3）低電流密度にさらされる時間を長くしたとき， 5 秒まで加工量が減少するものの, その後は増 加する

（4）不働態被膜では引張応力が働き，クラックが 生じやすくなるため，被膜生成時間が長くな ると加工量が増加すると思われる

\section{謝辞}

本研究は JSPS 科研費 JP18H01348 の助成を受け たものです.なお, 酸化被膜厚さの測定にご協力い ただいた山梨県産業技術センター, 残留応力の測 定にご協力いただいたパルステック工業株式会社 に感謝する.

\section{参考文献}

1) K.K. Saxena, J. Qian, D Reynaerts: A review on process capabilities of electrochemical micromachining and its hybrid variants, International Journal of Machine Tools \& Manufacture, 127 (2018) 28-56.

2) E. Uhlmann, B. Mullany, D. Biermann, K.P. Rajurkar, T. Hausotte, E. Brinksmeier: Process chains for highprecision components with micro-scale features, Annals of the CIRP, 65, 2 (2016) 549-572.

3) M. Kunieda, M. Yoshida, H. Yoshida, Y. kamatsu: Influence of micro indents formed by electrochemical jet machining on rolling bearing fatigue life, ASME, PED, 64 (1993) 693-699.

4) W. Natsu, T. Ikeda, M. Kunieda: Generating complicated surface with electrolyte jet machining, Precision Engineering, 31 (2007) 3339.

5) K. Yamamura: Development of numerically controlled local wet etching, Science and Technology of Advanced Materials, 8, 3 (2007) 158-161.

6) K. Endo, W. Natsu: Proposal and verification of electrolyte suction tool with function of gap-width detection, International Journal of Electrical Machining, 19 (2014) 34-39.

7) S. Hizume, W. Natsu: Influence of machining conditions on ECM characteristics of titanium alloy in shape generation by scanning tool electrode, Procedia CIRP, 68 (2018) 746-750.

8) S. Hizume, W. Natsu: Mechanism clarification and realization of scanning electrochemical machining of titanium alloys, Journal of Advanced Mechanical Design, Systems, and Manufacturing, 15, 5 (2021), JAMDSM0055.

9) D. Baehre, A. Ernst, K. Weißhaar, H. Natter, M. Stolpe, R. Busch: Electrochemical dissolution behavior of titanium and titanium-based alloys in different electrolytes, Procedia CIRP, 42 (2016) 137-142.

10) Y. Wang, Z. Xu, A. Zhang: Anodic characteristics and electrochemical machining of two typical $\gamma$-TiAl alloys and its quantitative dissolution model in $\mathrm{NaNO}_{3}$ solution, Electrochimica Acta, 331 (2020) 135429.

11) T. Kawanaka, M. Kunieda: Mirror-like finishing by electrolyte jet machining, Annals of the CIRP, 64, 1 
(2015) 237-240.

12) W. Liu, Z. Luo, M. Kunieda: Electrolyte jet machining of Ti1023 titanium alloy using $\mathrm{NaCl}$ ethylene glycol-based electrolyte, Journal of Materials Processing Technology, 283 (2020) 116731.

13) A. Sato, W. Natsu: Proposal and verification of area-limited electroplating with suction tool, International Journal of Electrical Machining, 20 (2015) 37-43.

14）岡田達弘：不働態皮膜の局部的破壊と孔食-動力 学的過程，防食技術, 36 (1987) 383-392.

15) I. Vrublevsky, V. Parkoun, V. Sokol, J.
Schreckenbach, G. Marx: The study of the volume expansion of aluminum during porous oxide formation at galvanostatic regime, Applied Surface Science, 222 (2004) 215-225.

16) D.T. Chin, K.W. Mao: Transpassive dissolution of mild steel in $\mathrm{NaNO}_{3}$ electrolytes, Journal of Applied Electrochemistry, 4 (1974) 155-161.

17） M. Datta, D. Landolt: Film breakdown on nickel under transpassive dissolution conditions in sodium nitrate solutions, Journal of Electrochemistry Society, 124, 4 (1977) 483-489.

（2021年8月23日受付） 